\title{
Quality Management in Dental Health Care: Present and Future Development
}

\author{
Jasmina Tekić1, Vidosav D. Majstorović ${ }^{2}$, Dejan Marković ${ }^{1}$, Angelina Nikodijević1, \\ Dragoslav Stamenković ${ }^{1}$ \\ 1School of Dentistry, University of Belgrade, Belgrade, Serbia; \\ ${ }^{2}$ Faculty of Mechanical Engineering, University of Belgrade, Belgrade, Serbia
}

\begin{abstract}
SUMMARY
The standards ISO 9000 series, brought in 1987, were the driving force for the development and application of quality management (QM) in various areas, including health care. Currently, there are over one million certificates for quality management (QMC), and they were main initiators of quality improvement. In addition to the model for quality management of products/services, other models are also in use. The aim of this study was to present methods and techniques for quality improvement of health services, with special emphasis on dental health care services (DHS), and possibility for enhancement.
\end{abstract}

Keywords: quality management; dental health care

\section{INTRODUCTION}

Quality management (QM) in dental health care (DHC), must be viewed as a system that provides the defined level of quality service for all users. The elements of quality of these services are: effectiveness of treatment, acceptability of treatment by users, distribution of treatment, effectiveness and continuity of DHS. Sometimes, there is confusion about the continuity of competence of the service, even though it is only one element of quality management. The concept of quality management is focused on the level of customer satisfaction.

\section{DEVELOPMENT OF THE CONCEPT OF HEALTH SERVICES QUALITY MANAGEMENT}

Quality assurance (QA) and quality management (QM) are not new concepts and models in health care and DHS, they have their own history. The first data is related to England, the year 1854, when nursing services became standardized [1]. In US, medical education programs became standardized in 1910. The reason for standardization was, as expressed in the official report of the US Government, that some educational institutions did not show medical credibility, and had poor educational quality. American College of Medicine in 1917 set the requirements that doctors should meet in order to carry on their practice in hospitals. These criteria were the first voluntary accredited program, established by the Joint Committee for Hospital Accreditation. In Canada, in 1958, the National Committee for medical institutions accreditation developed first national model. Later, in 1992, the
National Council for Accreditation of health institutions was established and by 2002 gave accreditation for 1934 institutions. These agencies require from the institutions to develop, implement and maintain the quality management program as basic framework for accreditation [2]. These examples were the first models for application of QA and QM models in health care, including DHS.

On the other hand, the theory and practice of E. Deming, in late forties and early fifties of last century, has changed the industry view on quality issues. A new industrial model of QM has been developed and implemented first in Japan and soon after in North America. It reduced production costs and improved product quality. The focus of Deming's QM model was customer satisfaction by applying the statistical models for quality management [3].

E. Deming's positive experience, particularly in the application of statistical methods, was the framework for the development and application of his concept and improving service quality in health care. The effort was put to achieve the quality of health services, through prevention. The objectives of quality were focused on patients' satisfaction [4].

Donabedian [2] was a pioneer in developing and implementing the model of quality assurance (QA) in health care. He defined the model that included the structure, the process and outputs from health care services, and was related to quality. The structure referred to buildings, equipment and drugs available to facilities, the process referred to rendering services to a patient and outputs referred to the parameters of services provided to the patient. Those elements represent the framework for the QM model of health care [2]. Rating output parameters of 
the service makes the base model for assessing the quality of healthcare. A specific issue is to define the set of output parameters for different types of quality (Table 1) [5].

Current QM theories suggest extending the model of quality parameters to other users of health institutions [5, $6,7]$. Donabedian generally considered patients as only users, and there is a proposal to expand the model to other stakeholders of health institutions: employees, owners, society and suppliers. Therefore, it becomes the model for excellence of health care service or DHS.

Detailed elaboration of dental services is shown in Table 1. For example, Preventive services and prophylaxis (the structure shown in Table 2) have 10 services and each one is defined by its characteristics and quality parameters. For illustration, the services: Fissure sealing and Removal of soft deposits, have defined characteristics and quality parameters (Table 2). The level of quality of provided services in this area is related to: the quality of dental materials and equipment used in delivering services, the quality and level of therapists' expertise and high quality of patients' dental health culture (knowledge, behavior and habits in regard to oral health) (Table 2) [5].

Some other approaches to the development and implementation of QM models in health care, has begun by developing the effective (planned) and efficient (the leastcost) model of quality management services. Thus, for example, Thomas et al. developed a special simulation model to optimize the cost of the service, taking care to achieve the objectives as planned. This example shows that the high quality goals can be achieved without high expenses [8].

QA and QM activities are now primarily related to the development and application of good practice, quality objectives and specialized models for improving service quality in this area (ISO 9001, TQM, BE). These activities are related to standardized procedure of service, user's feedback, review of management as well as annual reports and assessment through a third party. In North America, the models of good practice, TQM models and targets are mostly in use, while in Europe, and specially in England, the models of good practice, BE and ISO 9001 are in use. In the Far East, specially in Japan and Australia, TQM models and best practice are mostly used in this area. The main goal of all the activities is providing the users health services of the same or higher quality.

One of the most important methods for QA and QM analysis in health care practice is the use of a Questionnaire $[9,10]$. In defining the questionnaire, it is important to carefully define its structure, as well as the questions for each module of the questionnaire. The basic elements of each questionnaire should be: basic information about the user, his/her opinion on the quality of service, the behavior of health institutions staff to them, and possible service upgrading.

Another approach to this problem is detailed analysis of medical record for each patient, and quality assessment of provided service $[11,12]$. To use this approach, there should be the referent document according to which all documents will be reviewed. This is most frequently used concept of good practice in each area, including services related to DHS.

Beginning with the fact that wide range of health services is provided today, protocols are basic principles for the development and implementation of QA and QM methods. They are typical standards of good practice in specific fields. The first protocols were developed in the United States, by joint Commission for Accreditation of health institutions; there are 435 by today. They are standardized and serve as a base to measure the current level of practice QM in the analyzed field of health service. To assess their application in practice, there are two levels of judges [11]. In private practice, one of most commonly used method of support for QA and QM activities is a checklist [13]. The checklist provides control on application of a given protocol in rendering certain service. Investigations carried out in the US showed that this

Table 1. Classification of DHS quality parameters

Tabela 1. Klasifikacija usluga SZZ prema parametrima kvaliteta

\begin{tabular}{|c|c|c|c|}
\hline $\begin{array}{l}\text { Number } \\
\text { Broj }\end{array}$ & $\begin{array}{l}\text { Dental services/groups } \\
\text { Stomatološke usluge/grupe }\end{array}$ & $\begin{array}{l}\text { Main characteristics of the service } \\
\text { Osnovna obeležja usluga }\end{array}$ & $\begin{array}{l}\text { Parameters of service quality } \\
\text { Parametri kvaliteta usluge }\end{array}$ \\
\hline 1 & $\begin{array}{l}\text { Examinations and health education } \\
\text { Pregledi i zdravstveno vaspitanje }\end{array}$ & $\begin{array}{l}\text { National guides to good practice } \\
\text { Nacionalni vodič dobre prakse }\end{array}$ & $\begin{array}{l}\text { Harmonization of standards and accreditation of services } \\
\text { Usklađivanje standarda i akreditacija usluga }\end{array}$ \\
\hline 2 & $\begin{array}{l}\text { Orthodontic treatment } \\
\text { Ortodontska terapija }\end{array}$ & $\begin{array}{l}\text { Standardization of service } \\
\text { Standardizacija usluge }\end{array}$ & $\begin{array}{l}\text { Rules of implementation of standards } \\
\text { Poslovnik o primeni standarda }\end{array}$ \\
\hline 3 & $\begin{array}{l}\text { Prevention and prophylaxis } \\
\text { Prevencija i profilaksa }\end{array}$ & $\begin{array}{l}\text { Standardization of service } \\
\text { Standardizacija usluge }\end{array}$ & $\begin{array}{l}\text { Rules of implementation of standards } \\
\text { Poslovnik o primeni standarda }\end{array}$ \\
\hline 4 & $\begin{array}{l}\text { Dental therapy } \\
\text { Lečenje zuba }\end{array}$ & $\begin{array}{l}\text { Standardization of service } \\
\text { Standardizacija usluge }\end{array}$ & $\begin{array}{l}\text { Rules of implementation of standards } \\
\text { Poslovnik o primeni standarda }\end{array}$ \\
\hline 5 & $\begin{array}{l}\text { First aid and emergencies } \\
\text { Prva pomoć i hitna stanja }\end{array}$ & $\begin{array}{l}\text { National guides to good practice } \\
\text { Nacionalni vodič dobre prakse }\end{array}$ & $\begin{array}{l}\text { Harmonization of standards and accreditation of services } \\
\text { Usklađivanje standarda i akreditacija usluga }\end{array}$ \\
\hline 6 & $\begin{array}{l}\text { Prosthetic therapy } \\
\text { Protetička terapija }\end{array}$ & $\begin{array}{l}\text { Standardization of service } \\
\text { Standardizacija usluge }\end{array}$ & $\begin{array}{l}\text { Rules of implementation of standards } \\
\text { Poslovnik o primeni standarda }\end{array}$ \\
\hline 7 & $\begin{array}{l}\text { Tests, diagnosis and analysis } \\
\text { Testovi, dijagnostika i analiza }\end{array}$ & $\begin{array}{l}\text { National guides to good practice } \\
\text { Nacionalni vodič dobre prakse }\end{array}$ & $\begin{array}{l}\text { Harmonization of standards and accreditation of services } \\
\text { Usklađivanje standarda i akreditacija usluga }\end{array}$ \\
\hline 8 & $\begin{array}{l}\text { Periodontal therapy } \\
\text { Parodontološka terapija }\end{array}$ & $\begin{array}{l}\text { Standardization of service } \\
\text { Standardizacija usluge }\end{array}$ & $\begin{array}{l}\text { Rules of implementation of standards } \\
\text { Poslovnik o primeni standarda }\end{array}$ \\
\hline 9 & $\begin{array}{l}\text { Surgery - oral and maxillofacial } \\
\text { Hirurgija - oralna i maksilofacijalna }\end{array}$ & $\begin{array}{l}\text { Standardization of services } \\
\text { Standardizacija usluge }\end{array}$ & $\begin{array}{l}\text { Rules of implementation of standards } \\
\text { Poslovnik o primeni standarda }\end{array}$ \\
\hline 10 & $\begin{array}{l}\text { X ray services } \\
\text { Rendgen }\end{array}$ & $\begin{array}{l}\text { Standardization of services } \\
\text { Standardizacija usluge }\end{array}$ & $\begin{array}{l}\text { Rules of implementation of standards } \\
\text { Poslovnik o primeni standarda }\end{array}$ \\
\hline
\end{tabular}


Table 2. Classification of Prevention and Prophylaxis services with quality parameters

Tabela 2. Klasifikacija usluga iz grupe Preventiva i profilaksa sa parametrima kvaliteta

\begin{tabular}{|c|c|c|c|c|c|}
\hline \multirow{2}{*}{$\begin{array}{l}\text { Number } \\
\text { Broj }\end{array}$} & \multirow{2}{*}{$\begin{array}{l}\text { Dental services/groups } \\
\text { Stomatološke usluge/ } \\
\text { grupe }\end{array}$} & \multirow{2}{*}{$\begin{array}{l}\text { Main characteristics of } \\
\text { the service } \\
\text { Osnovna obeležja usluge }\end{array}$} & \multicolumn{3}{|c|}{ Parameters of service quality / Parametri kvaliteta usluge } \\
\hline & & & $\begin{array}{l}\text { Dental materials } \\
\text { Stomatološki materijali }\end{array}$ & $\begin{array}{l}\text { Therapy } \\
\text { Lečenje }\end{array}$ & $\begin{array}{l}\text { Patient } \\
\text { Pacijent }\end{array}$ \\
\hline 19 & $\begin{array}{l}\text { Soft deposits removal } \\
\text { Uklanjanje mekih naslaga }\end{array}$ & & & & \\
\hline 20 & $\begin{array}{l}\text { Fissure sealing } \\
\text { (per tooth) } \\
\text { Zalivanje fisura } \\
\text { (po zubu) }\end{array}$ & $\begin{array}{l}\text { Specialist in pedodontics: mecha- } \\
\text { nical removal of soft plaque from } \\
\text { the tooth using tooth brushes } \\
\text { and pastes, field isolation, drying } \\
\text { the tooth, coating the occlusal } \\
\text { surface by conditioning solutions, } \\
\text { flushing excess acid, drying the } \\
\text { teeth, sealant application, curing, } \\
\text { data entry in the medical record } \\
\text { Specijalista dečje i preventivne } \\
\text { stomatologije: mehaničko ukla- } \\
\text { njanje mekih naslaga sa zuba čet- } \\
\text { kicama i pastama, izolacija rad- } \\
\text { nog polja, sušenje zuba, premazi- } \\
\text { vanje okluzalne površine rastvo- } \\
\text { rima za kondicioniranje, ispiranje } \\
\text { viška kiseline, sušenje zuba, zali- } \\
\text { vanje fisura, polimerizacija, unos } \\
\text { podataka u dokumentaciju }\end{array}$ & $\begin{array}{l}\text { Level of quality for dental } \\
\text { material - sealant } \\
\text { Nivo kvaliteta stomatološ- } \\
\text { kog materijala - zalivača }\end{array}$ & $\begin{array}{l}\text { Manual dexterity of the the- } \\
\text { rapist (working with chil- } \\
\text { dren), recognizing and qu- } \\
\text { ality removal of soft plaque } \\
\text { from the tooth and strict } \\
\text { following the procedures for } \\
\text { the sealant application (soft } \\
\text { deposits removed, dry work } \\
\text { field, etc..) } \\
\text { Manuelna spretnost terape- } \\
\text { uta (rad sa decom), prepo- } \\
\text { znavanje i kvalitetno uklanja- } \\
\text { nje mekih naslaga sa zuba i } \\
\text { strogo pridržavanje propisa- } \\
\text { ne procedure za primenu za- } \\
\text { livača (uklonjene naslage, su- } \\
\text { vo radno polje itd.) }\end{array}$ & $\begin{array}{l}\text { Strict adherence } \\
\text { to the principles } \\
\text { of good oral hygi- } \\
\text { ene, control for } 6 \\
\text { months } \\
\text { Strogo pridržava- } \\
\text { nje principa do- } \\
\text { bre oralne higijene, } \\
\text { kontrola na šest } \\
\text { meseci }\end{array}$ \\
\hline 21 & $\begin{array}{l}\text { Local fluoride application of } \\
\text { medium concentration } \\
\text { Lokalna primena fluorida } \\
\text { srednje koncentracije }\end{array}$ & & & & \\
\hline 22 & $\begin{array}{l}\text { Serial application of con- } \\
\text { centrated fluoride } \\
\text { Serijska primena koncentro- } \\
\text { vanih fluorida }\end{array}$ & & & & \\
\hline 106 & $\begin{array}{l}\text { Removal of soft depo- } \\
\text { sits and polishing of teeth } \\
\text { per jaw } \\
\text { Uklanjanje mekih naslaga i } \\
\text { poliranje zuba po vilici }\end{array}$ & $\begin{array}{l}\text { Specialist: the preparation and } \\
\text { examination of the patient, de- } \\
\text { tection of plaque by staining, re- } \\
\text { moval of calculus by appropria- } \\
\text { te instruments; cleaning of teeth } \\
\text { using braches and pastes, spray } \\
\text { application, data entry in medi- } \\
\text { cal record. } \\
\text { Specijalista: priprema i pregled } \\
\text { pacijenta, otkrivanje plaka prebo- } \\
\text { javanjem, uklanjanje naslaga od- } \\
\text { govarajućim instrumentima, či- } \\
\text { śćenje zuba odgovarajućm četki- } \\
\text { cama i pastama, primena spreja, } \\
\text { unos podataka u dokumentaciju }\end{array}$ & $\begin{array}{l}\text { Level of quality dental } \\
\text { material for the detection } \\
\text { of dental plaque, the level } \\
\text { of quality of instruments } \\
\text { for cleaning teeth - br- } \\
\text { ush, level of qualitu of pa- } \\
\text { stes forthe removal of soft } \\
\text { deposits } \\
\text { Nivo kvaliteta stomato- } \\
\text { loškog materijala za ot- } \\
\text { krivanje zubnog plaka, ni- } \\
\text { vo kvaliteta instrumenata } \\
\text { za čišćenje zuba - četki- } \\
\text { ca, nivo kvaliteta pasta za } \\
\text { uklanjanje mekih naslaga }\end{array}$ & $\begin{array}{l}\text { The quality of the therapist } \\
\text { (detection of plaque, plaque } \\
\text { removal with clearly defined } \\
\text { procedures, patient training } \\
\text { for proper oral hygiene- se- } \\
\text { lection of brushes, fluoride } \\
\text { toothpaste, the optimal du- } \\
\text { ration of brushing the teeth) } \\
\text { Kvalitet rada terapeuta (ot- } \\
\text { krivanje plaka, uklanjanje } \\
\text { plaka po jasno definisanoj } \\
\text { proceduri, obuka pacijenta u } \\
\text { pravilnom održavanju oralne } \\
\text { higijene - izbor četkice, pa- } \\
\text { ste s fluorom, optimalna du- } \\
\text { žina trajanja pranja zuba) }\end{array}$ & $\begin{array}{l}\text { Strict following } \\
\text { the principles of } \\
\text { good oral hygie- } \\
\text { ne, high quality of } \\
\text { knowledge, beha- } \\
\text { vior and habits of } \\
\text { patients in relation } \\
\text { to oral health } \\
\text { Strogo pridržava- } \\
\text { nje principa dobre } \\
\text { oralne higijene, vi- } \\
\text { sok nivo kvaliteta } \\
\text { znanja, ponašanja i } \\
\text { navika pacijenata } \\
\text { odnosu na oralno } \\
\text { zdravlje }\end{array}$ \\
\hline 138 & $\begin{array}{l}\text { Elimination of oral mucous } \\
\text { membrane irritation } \\
\text { Oslobađanje od iritacija } \\
\text { oralne sluzokože }\end{array}$ & & & & \\
\hline 200 & $\begin{array}{l}\text { Fixation of traumatised } \\
\text { teeth by dental splint } \\
\text { Fiksacija traumatski luksira- } \\
\text { nih zuba splintom ili šinom }\end{array}$ & & & & \\
\hline 201 & $\begin{array}{l}\text { Fixation of luxated teeth by } \\
\text { composite splint } \\
\text { Fiksacija traumatski luksi- } \\
\text { ranih zuba kompozitnim } \\
\text { splintom ili šinom }\end{array}$ & & & & \\
\hline 202 & $\begin{array}{l}\text { Removing the splint } \\
\text { Uklanjanje splinta ili šine }\end{array}$ & & & & \\
\hline 237 & $\begin{array}{l}\text { Training patients to excer- } \\
\text { cize for rehabilitation of the } \\
\text { temporo mandibular joint } \\
\text { Obuka pacijenta za izvođe- } \\
\text { nje funkcionalnih vežbi za } \\
\text { rehabilitaciju temporoman- } \\
\text { dibularnog zgloba }\end{array}$ & & & & \\
\hline
\end{tabular}


Table 3. The review of methods for improving health service quality which are applicable in DHS

Tabela 3. Pregled metoda za unapređenje kvaliteta zdravstvene usluge koje se mogu primeniti i u SZZ

\begin{tabular}{|c|l|l|}
\hline $\begin{array}{c}\text { Number } \\
\text { Broj }\end{array}$ & $\begin{array}{l}\text { Method } \\
\text { Metoda }\end{array}$ & $\begin{array}{l}\text { Main characteristics } \\
\text { Osnovne odlike }\end{array}$ \\
\hline 1 & $\begin{array}{l}\text { Quality Assurance } \\
\text { Obezbeđenje kvaliteta }\end{array}$ & $\begin{array}{l}\text { Quality Assurance } \\
\text { Obezbedenje kvaliteta }\end{array}$ \\
\hline 2 & $\begin{array}{l}\text { Quality Management } \\
\text { Upravljanje kvalitetom }\end{array}$ & $\begin{array}{l}\text { Quality Management } \\
\text { Upravljanje kvalitetom }\end{array}$ \\
\hline 3 & $\begin{array}{l}\text { Audit of health institution } \\
\text { Audit zdravstvene ustanove }\end{array}$ & $\begin{array}{l}\text { National guidelines of good practice } \\
\text { Nacionalni vodiči dobre prakse }\end{array}$ \\
\hline 4 & ISO 9001 & $\begin{array}{l}\text { Certified Quality Management model } \\
\text { Sertifikovani model upravljanja kvalitetom }\end{array}$ \\
\hline 5 & $\begin{array}{l}\text { Total Quality Management } \\
\text { Upravljanje ukupnim kvalitetom }\end{array}$ & $\begin{array}{l}\text { Total Quality Management } \\
\text { Upravljanje ukupnim kvalitetom }\end{array}$ \\
\hline 6 & $\begin{array}{l}\text { Business Excellence } \\
\text { Poslovna izvrsnost }\end{array}$ & $\begin{array}{l}\text { Business Excellence } \\
\text { Poslovna izvrsnost }\end{array}$ \\
\hline
\end{tabular}

method can be very effective, but it requires the independent evaluators, who would compare planned/ carried out activities from the checklist, prescribed protocols and their agreement. By that way, there is a reliable information on rendered service, but also on gradation of the provided service, which makes this method (checklist) as one of main QA methods.

The following method is used to analyze the achieved level of QM and the application of ISO 9001 certification (QMS), what is assessed/ certified by a third party. The control on the application of these techniques is checked first by internal controls. It is important to emphasize that the level of QM practice depends on the characteristics and quality of an evaluator: his knowledge, experience, abilities and personal characteristics. That approach is directly related to the development of national/ international accreditation and certification system which standards and supplements are related to the health care (IWA 1 document). The model (ISO 9001) assesses the approach to the resource management, by service performance and monitoring, measuring and improving the service. It is important to mention that the QMS can and should be the base for the development and implementation of TQM and BE (Table 3) [5].

In the area of DHS, the information on the implementation of QA and QM method is lacking, confirming the fact that this area is still developing.

\section{QUALITY MANAGEMENT AND QUALITY CONTROL - TECHNIQUES IN HEALTH CARE PRACTICE}

The fundamental aspect for improving quality of health care services is to measure their performance. Current practice in this area uses two approaches: 1) effectiveness - planned/ done; and 2) efficiency - embedded resources/realized gain (profit). To be able to implement that approach into the practice, health care provider must have and use: rules, procedures, records, guides, plans, programs and guidelines. The element to begin with, in the development and implementation, is the strategy for QM of health organization as well as the management and staff training in this area. It is believed that the model of education under the principle of the circle of quality is the best method for education and quality improvement in an organization. Quality circles were developed in Japan, in 60's of last century, when Professor K. Ishikawa, using Deming's QM method, implemented the project of quality improvement in Komatsu Company (the most famous global manufacturer of mining and construction machinery in the world). The circle represents the team of employees ( $\min 3, \max 7)$, who continuously work on improvement of the quality of organization. There are about one million of those discussion groups in Japan, and about 100,000 in Western Europe. The main key for success of this concept is self-initiative, motivation and commitment to quality issues [3].

The next approach to solving problems of the effectiveness of QA and QM models is the quality program. It is made for the area/ organization and defines methods and resources for quality improvement and their implementation. It includes: $\mathrm{QM}$ activities, their objectives, the area and extent of activity, frequency and annual performance plans. One of the most famous examples in this area is the program QUARTZ (US), which relates to improving the quality of mental health. Evaluation of the practice is carried out using defined criteria, which have been developed to support this program [9].

Guidelines for good clinical practice are perhaps the best examples of good QM practice and their evaluation. Their success is assessed by the level of development and accomplishment of strategies for their implementation, as well as the results achieved in their use (in writing). These guidelines are developed and used the most in the US and Europe. Their practical use and experience with them enables their modifications and improvement through feedback, which significantly contributes to the quality of service improvement. Good clinical practice can be viewed as a standard that has defined indicators, measurable for the service they relate to. They represent the framework for the development and application of QM organization model, as well as the base for employees' education and knowledge innovation in the area to which they relate. The experience showed that the guidelines were major contributions to the development and application of new methodologies in QM. Thus, for example, the American Association for pain has developed five principles in the form of a questionnaire, by which the success of treatment is assessed. Also, based on the same standard, the 
other questionnaire that assesses a patient satisfaction has been developed. Using those two questionnaires, the management of health facilities assesses the level of quality of provided service [7].

Using statistical indicators, QA methodology is the model that allows comparison of two sample parameters, expectations and evaluation of customer satisfaction. In fact, this model compares two customer's reports that relate to the quality of health care service. The first group of parameters relates to the expectations regarding the planned service, and the other gives the parameters of satisfaction with provided service. Detected differences are the framework for improving quality of the service and represent determined values of quality indicators for specific service [9].

Accreditation of health institutions is QM tool, widely used worldwide in the last decade. Those principles are base for institution accreditation as well as the assessment of $\mathrm{QM}$ in the practice, achieved in particular institution.

American College of Radiology has developed voluntary standards for providing services in clinical screening. This program has four phases, and the accreditation of the institution is based on meeting its requirements. At each stage: the equipment, the characteristics of patients, the staff qualifications, the review of the results achieved by rendering that service, as well as the evaluation and quality control of the process are assessed [6].

Management of availability is next methodology of QA, based on accessibility of the procedures, guidelines and good practice when needed. The model is focused on reducing the time from the onset of acute conditions to its full medical care. The records of these procedures by which all designed parameters are determined also represent the current level of QM [12].

Benchmarking is the method for determining the achieved level of quality of health care service, and can be used at local, national and international level [7]. For example, each level of health facilities, from the highest to the lowest level (individual or department) can be a benchmark reference. By their comparison, determined values for the quality of service are obtained. However, the drawback of this method is inability to compare different organizations because the various organizations operate with different influence parameters and comparison is brought into question.

QA methodologies also include the use of techniques for self-evaluation. They allow the health institution to detect weak points in the model of service, to improve them and thus to improve its quality. This method uses several records for monitoring and measuring the quality of provided service (cumulative map, histogram, etc.). By using them, the comparison of planned/ actual quality objectives is provided [5].

Variations or analysis of variance (ANOVA) also falls into the category of tools for self-evaluation of achieved level of quality product/ service [4]. It gives possibility to determine the factors and causes that lead to deviations from set values.

For self-assessment of service quality, a professional portfolio is increasingly in use. For this technique, different software products were developed, and its essence is to define the necessary framework of practice, requirements for improvement, a set of activities for implementing the service, parameters for evaluating the effectiveness

Table 4. The review of QA/QM techniques which are applicable in DHS

Tabela 4. Pregled tehnika obezbeđenja kvaliteta i upravljanja kvalitetom koje se mogu primeniti i u SZZ

\begin{tabular}{|c|c|c|}
\hline $\begin{array}{l}\text { Number } \\
\text { Broj }\end{array}$ & $\begin{array}{l}\text { Technique } \\
\text { Tehnika }\end{array}$ & $\begin{array}{l}\text { Main characteristics } \\
\text { Osnovne odlike }\end{array}$ \\
\hline 1 & $\begin{array}{l}\text { Circles of quality } \\
\text { Kružoci kvaliteta }\end{array}$ & $\begin{array}{l}\text { Quality improvement } \\
\text { Unapređenje kvaliteta }\end{array}$ \\
\hline 2 & $\begin{array}{l}\text { Program of Quality } \\
\text { Program kvaliteta }\end{array}$ & $\begin{array}{l}\text { Strategic quality monitoring } \\
\text { Strateško praćenje kvaliteta }\end{array}$ \\
\hline 3 & $\begin{array}{l}\text { Guidelines for good clinical practice } \\
\text { Vodiči dobre kliničke prakse }\end{array}$ & $\begin{array}{l}\text { Standardization of service } \\
\text { Standardizacija usluge }\end{array}$ \\
\hline 4 & $\begin{array}{l}\text { Accreditation of health institutions } \\
\text { Akreditacija zdravstvenih ustanova }\end{array}$ & $\begin{array}{l}\text { Standardization of service } \\
\text { Standardizacija usluge }\end{array}$ \\
\hline 5 & $\begin{array}{l}\text { Statistical indicators } \\
\text { Statistički indikatori }\end{array}$ & $\begin{array}{l}\text { Quality monitoring } \\
\text { Praćenje kvaliteta }\end{array}$ \\
\hline 6 & $\begin{array}{l}\text { Standards for good clinical practice } \\
\text { Standardi dobre kliničke usluge }\end{array}$ & $\begin{array}{l}\text { Quality improvement } \\
\text { Unapređenje kvaliteta }\end{array}$ \\
\hline 7 & $\begin{array}{l}\text { Management of Availability } \\
\text { Upravljanje raspoloživim sredstvima }\end{array}$ & $\begin{array}{l}\text { Quality monitoring } \\
\text { Praćenje kvaliteta }\end{array}$ \\
\hline 8 & $\begin{array}{l}\text { Benchmarking } \\
\text { Reper }\end{array}$ & $\begin{array}{l}\text { Quality monitoring } \\
\text { Praćenje kvaliteta }\end{array}$ \\
\hline 9 & $\begin{array}{l}\text { Self- evaluation } \\
\text { Samoocenjivanje }\end{array}$ & $\begin{array}{l}\text { Quality improvement } \\
\text { Unapređenje kvaliteta }\end{array}$ \\
\hline 10 & $\begin{array}{l}\text { Variation/ANOVA } \\
\text { Varijacija/analiza varijansi }\end{array}$ & $\begin{array}{l}\text { Quality monitoring } \\
\text { Praćenje kvaliteta }\end{array}$ \\
\hline 11 & $\begin{array}{l}\text { Professional portfolio } \\
\text { Profesionalni portfolio }\end{array}$ & $\begin{array}{l}\text { Quality improvement } \\
\text { Unapređenje kvaliteta }\end{array}$ \\
\hline 12 & $\begin{array}{l}\text { Consensus statement } \\
\text { Konsenzus izjava }\end{array}$ & $\begin{array}{l}\text { Quality improvement } \\
\text { Unapređenje kvaliteta }\end{array}$ \\
\hline 13 & $\begin{array}{l}\text { Continuous Education } \\
\text { Kontinuirana edukacija }\end{array}$ & $\begin{array}{l}\text { Quality improvement } \\
\text { Unapređenje kvaliteta }\end{array}$ \\
\hline
\end{tabular}


of service and the mode of revising the model in practice. The basic characteristic of this method is to promote and support the model of continuous improvement of employees' knowledge in the field of QM.

One of the most effective QM techniques is also a written consent $[13,14]$. This technique is similar to guidelines for good clinical practice, and it is useful in health institutions. It is based on group of experts meetings, and through a panel discussion generating the statement of quality management of a specific service in a medical institution. The main characteristic of this technique is to develop and support local good practice, specific for each health institution.

The QM technique that has a long history of application in this field is continuing education. It is based on the systematic approach for planning, implementing, evaluating and reviewing of completed training. On the other hand, this training should be segmented deeply in organizational structure of health institutions (management, quality improvement team, experts...) (Table 4) [5].

\section{CONCLUSION}

DHS is an important aspect of health care in one country. In last twenty years, this form of health care in our country has undergone various changes, particularly in organization. Currently, a special attention is given to this type of health care, especially in the area of quality improvement. There are several methods available, however, QMS is an important model, which can be a good base for further improvements - TQM and BE model.

\section{REFERENCES}

1. Bilawka E, Craig BJ. Quality assurance in health care: past, present and future. Int I Dent Hyg. 2005; 1:159-68.

2. Donabedian A. Models of quality assurance. I Med Systems. 1988; 12:307-13.

3. Walton M. The Deming Management Methods. New York: The Berkley Publishing Group; 1986.

4. Epstain A. Performance report on quality. N Engl J Med. 1999; 16:157-61.

5. Tekic J. R \& D model of excellence in dental health care [PhD thesis in progress]. Belgrade: Faculty of Dentistry; 2010.

6. Minkman M, Ahaus K, Huijsman R. Performance improvement based on integrated quality management models: what evidence do we have? A systematic literature review. Int I Qual Health Care. 2007; 19:90-104.

7. Walshe K. Understanding what works and why in quality improvement: the need for theory-driven evaluation. Int J Qual Health Care. 2007; 19:57-9.

8. McDowel I, Newell C. Measuring Health - A Guide to Rating Scales and Questionnaires. New York: Oxford University Press; 1996.

9. Leiper R, Hill R. Evaluating Quality Assurance: an empirical programme evaluation of the pilot implementation of the QUARTZ system. London: RDP/Sainsbury Centre for Mental Health; 1993.

10. Ammentorp J. Electronic questionnaires for measuring parent satisfaction and as a basis for quality improvement. Int I Qual Health Care. 2007; 19:120-4.

11. Goldman R. The reliability of peer assessment of quality care. JAMA. 1992; 267:958-60.

12. Kane R. The challenge of explaining why quality improvement has not done better. Int J Qual Health Care. 2007; 19:8-10.

13. Arah O. A conceptual framework for the OECD Health Care Quality Indicators Project. Int I Qual Health Care. 2006; 18:5-13.

14. Fromberg R. The Joint Commission Guide to Quality Assurance. Chicago: Joint Commission on Accreditation of Healthcare Organizations; 1988. 


\title{
Upravljanje kvalitetom u stomatološkoj zdravstvenoj zaštiti: stanje i budući razvoj
}

\author{
Jasmina Tekić1, Vidosav D. Majstorović², Dejan Marković1, Angelina Nikodijević1, Dragoslav Stamenković ${ }^{1}$ \\ 'Stomatološki fakultet, Univerzitet u Beogradu, Beograd, Srbija; \\ ${ }^{2}$ Mašinski fakultet, Univerzitet u Beogradu, Beograd, Srbija
}

\begin{abstract}
KRATAK SADRŽAJ
Standardi serije ISO 9000, doneti 1987. godine, bili su pokretač razvoja i primene principa upravljanja kvalitetom u različitim oblastima, pa i u zdravstvenoj zaštiti. Danas u svetu postoji više od milion sertifikata za upravljanje kvalitetom, tako da se može reći da su oni bili osnovni pokretač unapređenja kvaliteta. Pored modela za upravljanje kvalitetom proizvoda i usluga, danas se u ovoj oblasti koriste različiti modeli. Cilj ovog rada je bio da se predstave metode i tehnike unapređenja kvaliteta zdravstvenih usluga, $\mathrm{s}$ posebnim osvrtom na usluge stomatološke zdravstvene zaštite i aspekt unapređenja kvaliteta u njoj.
\end{abstract}

Ključne reči: upravljanje kvalitetom; stomatološka zdravstvena zaštita

\section{UVOD}

Upravljanje kvalitetom u stomatološkoj zdravstvenoj zaštiti (SZZ) mora se posmatrati kao sistem koji obezbeđuje definisani nivo kvaliteta usluge za sve korisnike. Elementi kvaliteta ove usluge su: efektivnost tretmana, prihvatljivost tretmana za korisnika, rasprostranjenost tretmana, efektivnost i kontinuitet SZZ. Ponekad se konfuzija stvara oko kontinuiteta kompetencije ove usluge, koji je, u stvari, samo jedan od elemenata upravljanja kvalitetom. Težište koncepta upravljanja kvalitetom usmereno je na nivo zadovoljstva korisnika usluge.

\section{RAZVOJ KONCEPTA UPRAVLJANJA KVALITETOM ZDRAVSTVENE USLUGE}

Obezbeđenje kvaliteta i upravljanje kvalitetom su koncepti i modeli koji u zdravstvenoj zaštiti i SZZ postoje već dugo. Prvi podaci vezani su za 1854. godinu, kada su u Engleskoj standardizovane procedure sestrinske nege [1]. U Sjedinjenim Američkim Državama su 1910. godine standardizovani programi medicinskog obrazovanja. Razlog za ovo je bila činjenica izneta u zvaničnom izveštaju Vlade SAD da je uočeno da neke obrazovne medicinske institucije nemaju kredibilitet i imaju nizak nivo kvaliteta obrazovanja svojih studenata. Američki koledž za medicinu je 1917. godine doneo kriterijume koje lekari treba da zadovolje da bi mogli da vrše svoju praksu u bolnicama. Ovi kriterijumi su predstavljali prvi dobrovoljni akreditovani program, uspostavljen od zajedničkog Komiteta za akreditaciju bolnica. U Kanadi je 1958. godine od Nacionalnog komiteta za akreditaciju zdravstvenih ustanova razvijen prvi nacionalni model. Kasnije, 1992. godine, uspostavljen je Nacionalni savet za akreditaciju zdravstvenih ustanova, koji je do 2002. godine akreditovao 1.934 ustanove. Ove agencije od ustanova zahtevaju da razvijaju, primenjuju i održavaju program upravljanja kvalitetom, kao osnovni akreditacioni okvir [2]. Ovo su bili prvi primeri primene modela obezbeđenja kvaliteta i upravljanja kvalitetom u zdravstvenoj zaštiti, uključujući i SZZ.

$S$ druge strane, teorija i praksa E. Deminga (Deming) krajem četrdesetih i početkom pedesetih godina dvadesetog veka izmenili su industrijski pogled na probleme kvaliteta. Stvoren je novi industrijski model upravljanja kvalitetom, koji je prvo primenjen u Japanu, a kasnije i u Severnoj Americi. On je, pre svega, doneo smanjenje troškova proizvodnje i unapređenje kvaliteta proizvoda. Fokus Demingovog modela upravljanja kvalitetom bio je na zadovoljenju zahteva kupaca, primenom statističkih modela za upravljanje kvalitetom [3].

Pozitivna iskustva iz prakse Deminga, posebno u oblasti primene statističkih metoda, bili su okvir za razvoj i primenu ovog koncepta i unapređenje kvaliteta usluga u zdravstvenoj zaštiti. Težnja primene ovih metoda bila je da se kroz mere prevencije obezbedi ostvarivanje ciljeva kvaliteta u odnosu na pacijenta korisnika zdravstvene usluge. Ciljevi kvaliteta su bili usmereni na zadovoljenje zahteva pacijenata [4].

Donabedijan (Donabedian) [2] je bio pionir u razvoju i primeni modela obezbeđenja kvaliteta u zdravstvenoj zaštiti. On je definisao model koji obuhvata strukturu, proces i izlaze iz usluge zdravstvene zaštite koji se odnose na kvalitet. Struktura se odnosi na zgrade, opremu i lekove kojima raspolaže ustanova, proces se odnosi na pružanje usluga pacijentu, a izlazi na parametre obavljene usluge u odnosu na pacijenta. Ovi elementi predstavljaju okvir modela za upravljanje kvalitetom zdravstvene zaštite [2]. Ocenjivanje izlaznih parametara ove usluge čini polazni model za ocenjivanje i kvaliteta zdravstvene zaštite. Posebno pitanje koje se ovde postavlja jeste definisanje izlaznih parametara kvaliteta različitih tipova (Tabela 1) [5].

Današnje teorije upravljanja kvalitetom predlažu da se ovaj model proširi parametrima kvaliteta koji se odnose i na ostale interesne grupe zdravstvene ustanove $[5,6,7]$. Donabedijan [2] uglavnom posmatra samo korisnike (pacijente), a ovde se predlaže da se ovaj model proširi i na ostale interesne grupe zdravstvene ustanove: zaposlene, vlasnike, društvo i isporučioce. Dakle, reč je o modelu izvrsnosti za uslugu zdravstvene zaštite, odnosno SZZ.

Kada se, kao što je naznačeno u tabeli 1 , detaljno razrade usluge iz grupe stomatoloških usluga, dobija se, na primer, da grupa Preventiva i profilaksa (njena struktura koja je prikazana u tabeli 2) ima 10 stomatoloških usluga sa definisanim odlikama i parametrima kvaliteta za svaku posebno. Radi ilustracije ove klasifikacije, za usluge zalivanja fisura i uklanjanje mekih naslaga detaljno su definisane odlike i parametri kvaliteta (Tabela 2). Može se zaključiti da se nivo kvaliteta pružene usluge u ovoj oblasti odnosi na kvalitet stomatoloških materijala i uređaja koji se primenjuju pri vršenju usluge, kvalitet i nivo 
stručnosti terapeuta, odnosno visok nivo kvaliteta zdravstvene stomatološke kulture pacijenta (znanje, ponašanje i navike u odnosu na oralno zdravlje) [5].

Neki drugi prilazi razvoju i primeni modela upravljanja kvalitetom u zdravstvenoj zaštiti polazili su od toga da se razvije efektivan (planski) i efikasan (s najmanjim troškovima) model upravljanja kvalitetom ove usluge. Tako su, na primer, Tomas (Thomas) i saradnici razvili poseban simulacioni model za optimizaciju troškova ove usluge, vodeći računa o tome da se ostvare planirani ciljevi kvaliteta. Ovaj primer pokazuje da se visoki ciljevi kvaliteta mogu ostvariti i bez visokih troškova [8].

Aktivnosti obezbeđenja kvaliteta i upravljanja kvalitetom danas se, pre svega, odnose na razvoj i primenu dobre prakse, ciljeva kvaliteta i specijalizovanih modela za unapređenje kvaliteta usluge (ISO 9001, upravljanje ukupnim kvalitetom, poslovna izvrsnost) u ovoj oblasti. Ove aktivnosti se odnose na standardizovanu praksu usluge, povratne informacije od korisnika, preispitivanja menadžmenta kroz godišnje izveštaje i ocenjivanje od strane trećih lica. U Severnoj Americi se najviše primenjuju modeli dobre prakse, modeli upravljanja ukupnim kvalitetom i ciljevi kvaliteta, a u Evropi (posebno u Engleskoj) modeli dobre prakse, poslovne izvrsnosti i ISO 9001. Na Dalekom istoku, u Japanu i Australiji najviše se koriste modeli ukupnog upravljanja kvalitetom i najbolja praksa u ovoj oblasti. Osnovi cilj svih aktivnosti jeste da se korisnicima usluga zdravstvene zaštite pruže usluge istog ili višeg kvaliteta.

Jedna od najvažnijih metoda analize obezbeđenja kvaliteta i upravljanja kvalitetom zdravstvene usluge u praksi jeste korišćenje upitnika $[9,10]$. Pri definisanju upitnika važno je pažljivo odrediti njegovu strukturu i pitanja za svaki modul. Osnovni elementi svakog upitnika treba da budu: osnovni podaci o korisniku, njegovo mišljenje o kvalitetu usluge, o odnosu osoblja zdravstvene ustanove prema njima i o tome šta bi trebalo unaprediti u datoj usluzi. Drugi prilaz ovoj problematici je detaljna analiza medicinske dokumentacije svakog pacijenta, gde se može oceniti nivo kvaliteta s aspekta primenjene procedure određene usluge $[11,12]$. Za korišćenje ovog prilaza potrebno je imati referentni dokument na osnovu kojeg će se ova dokumentacija preispitivati, što je danas najčešći koncept dobre prakse za svaku oblast ovih usluga, pa i usluga iz oblasti SZZ.

Polazeći od činjenice da se danas koristi širok dijapazon zdravstvenih usluga, protokoli su jedan od osnovnih postulata razvoja i primene metoda obezbeđenja kvaliteta i upravljanja kvalitetom ovih usluga. Oni predstavljaju tipične standarde dobre prakse za pojedine oblasti. Prve protokole razvila je Komisija za akreditaciju zdravstvenih ustanova u SAD, a do danas ih je 435. Standardizovanog su tipa i na osnovu njih se može meriti ostvareni nivo prakse upravljanja kvalitetom u analiziranoj oblasti zdravstvene usluge. Za ocenjivanje njihove primene u praksi postoje dva nivoa ocenjivača [11]. U privatnoj praksi jedan od najčešće primenjivanih metoda podrške aktivnostima obezbeđenja kvaliteta i upravljanja kvalitetom je kontrolna lista [13]. Pomoću nje se obezbeđuje kontrola primene datog protokola pri vršenju određene usluge. Istraživanja izvedena u SAD pokazuju da ova metoda može da bude vrlo efikasna, ali su potrebni nezavisni ocenjivači, koji bi poredili planirane, odnosno izvršene aktivnosti s kontrolne liste, propisane protokole i međusobnu usaglašenost. Na taj način se dolazi do pouzdanih podataka o izvršenoj usluzi i njenom stepenu, što kontrolne liste čini jednom od osnovnih metoda upravljanja kvalitetom.
Sledeća metoda koja se primenjuje za analizu dostignutog nivoa upravljanja kvalitetom i primenu sertifikata ISO 9001, gde se ocenjivanje (sertifikacija) vrši preko trećih lica, naziva se sistem upravljanja kvalitetom. Kontrola primene ovih tehnika prvo se vrši internim proverama. Važno je istaći da nivo utvrđene prakse upravljanja kvalitetom zavisi od odlika i kvaliteta ocenjivača: njegovog znanja, iskustva, sposobnosti i ličnih osobina. Ovaj prilaz je u direktnoj vezi s razvojem nacionalnog, odnosno međunarodnog sistema akreditacije i sertifikacije za ove standarde, odnosno njihove dodatke koji se odnose na zdravstvenu zaštiti (dokument IWA 1). Model ISO 9001 ocenjuje pristup upravljanja resursima vršenjem usluge i praćenjem, merenjem $i$ unapređenjem te usluge. Važno je napomenuti da sistem upravljanja kvalitetom može i treba da bude osnova za razvoj i primenu upravljanja ukupnim kvalitetom i poslovnom izvrsnošću (Tabela 3) [5].

U oblasti SZZ očigledan je nedostatak informacija o primeni metoda obezbeđenja kvaliteta i upravljanja kvalitetom, čime se potvrđuje činjenica da se ova oblast usluga i dalje razvija.

\section{UPRAVLJANJE KVALITETOM I KONTROLA KVALITETA - TEHNIKE U PRAKSI ZDRAVSTVENE ZAŠTITE}

Osnovni aspekt unapređenja kvaliteta usluga u zdravstvenoj zaštiti je merenje njihovog učinka. Dosadašnja praksa u ovoj oblasti koristi dva pristupa: 1) efektivnost - planirano u odnosu na urađeno; i 2) efikasnost - uloženi resursi u odnosu na ostvarenu korist (dobit). Da bi se prvi pristup mogao primeniti u praksi, zdravstvena organizacija mora imati i koristiti: poslovnik, procedure, zapise, vodiče, planove, programe i uputstva. Polazni element za razvoj i primenu je strategija upravljanja kvalitetom zdravstvene organizacije, kao i obrazovanje menadžmenta i zaposlenih u ovoj oblasti. Smatra se da je model obrazovanja prema principu kružoka kvaliteta najbolja metoda obrazovanja, odnosno unapređenja kvaliteta rada u jednoj organizaciji. Kružoci kvaliteta su razvijeni u Japanu šezdesetih godina dvadesetog veka, gde je profesor K. Išikava (Ishikawa) u kompaniji Komatsu (najpoznatiji svetski proizvođač rudarskih i građevinskih mašina u svetu) realizovao projekat unapređenja kvaliteta primenom Demingovih metoda upravljanja kvalitetom. Kružok predstavlja tim zaposlenih (najmanje tri, a najviše sedam) koji neprekidno radi na problemu unapređenja kvaliteta u organizaciji. Danas ovih kružoka u Japanu ima oko milion, dok ih, recimo, u zapadnoj Evropi ima oko 100.000. Osnovni aspekt uspeha ovoga koncepta je samoinicijativa, motivacija i predanost pitanjima kvaliteta [3].

Sledeći pristup rešavanju problema efektivnosti modela obezbeđenja kvaliteta i upravljanja kvalitetom je program kvaliteta. On se pravi za oblast, odnosno organizaciju i definiše metode i resurse za unapređenje kvaliteta i njihovu primenu. Sadrži: aktivnosti upravljanja kvalitetom, njihove ciljeve, oblast i širinu delovanja, frekvenciju i godišnje planove izvođenja. Jedan od najpoznatijih primera iz ove oblasti je program QUARTZ (SAD), koji se odnosi na unapređenje kvaliteta mentalnog zdravlja. Ocenjivanje u praksi se vrši pomoću definisanih kriterijuma koji su razvijeni kao podrška ovom programu [9].

Vodiči dobre kliničke prakse su možda najbolji primer dobre prakse upravljanja kvalitetom i njihove ocene. Efektivnost njihove primene se ocenjuje nivoom razvoja i primene strategije 
njihove implementacije, kao i ostvarenim rezultatima u primeni (zapisi). Ovi vodiči su najviše razvijeni i primenjeni u SAD i Evropi. Njihova praktična primena i iskustva u njoj preko povratne sprege omogućuju njihovu izmenu i unapređenje, što značajno doprinosi i unapređenju kvaliteta usluge. Dobra klinička praksa se može posmatrati i kao standard, koji ima definisane indikatore, merljive za uslugu na koju se odnose. Oni su okvir za razvoj i primenu modela upravljanja kvalitetom za organizaciju, ali i baza za obrazovanje zaposlenih i inovaciju znanja iz oblasti na koju se odnose. Dosadašnja iskustva pokazuju da su vodiči značajno doprineli razvoju i primeni novih metodologija upravljanja kvalitetom. Tako je, na primer, Američko udruženje za bol razvilo pet standarda u obliku upitnika pomoću kojeg se ocenjuje uspešnost lečenja pacijenta. Takođe je na osnovu ovog standarda razvijen drugi upitnik kojim se ocenjuje zadovoljstvo pacijenta. Koristeći ova dva Upitnika, menadžment zdravstvene ustanove ocenjuje i nivo kvaliteta obavljene usluge [7].

Metodologija obezbeđenja kvaliteta primenom statističkih indikatora jeste model koji omogućuje poređenje parametara dva uzorka ocenjivanjem očekivanja i zadovoljstva korisnika. Naime, ovaj model poredi dva mišljenja korisnika koja se odnose na kvalitet usluge zdravstvene zaštite. Prva grupa parametara se odnosi na očekivanja korisnika u vezi s planiranom uslugom, a druga na zadovoljstvo korisnika pruženom uslugom. Razlike koje se pri tome uoče predstavljaju okvir za unapređenje kvaliteta ove usluge i determinisane vrednosti indikatora kvaliteta određene usluge [9].

Akreditacija zdravstvenih ustanova je alat upravljanja kvalitetom koji ima široku primenu u svetu u poslednjoj deceniji. $\mathrm{Na}$ osnovu toga vrši se akreditacija ovih ustanova i ocenjuje dostignuti nivoi prakse upravljanja kvalitetom u određenoj ustanovi.

Američki koledž za radiologiju je razvio dobrovoljne standarde za izvođenje usluga kliničkog skrininga. Ovaj program ima četiri faze, a njihovim ispunjenjem se vrši akreditacija ove ustanove. U svakoj fazi se ocenjuju oprema, odlike pacijenata i kvalifikacije zaposlenog osoblja, preispituju ostvareni rezultati pružene usluge i ocenjuje kontrola kvaliteta celog procesa [6].

Upravljanje raspoloživim sredstvima je sledeća metoda obezbeđenja kvaliteta. Reč je o tome da procedure, uputstva i dobra praksa budu raspoloživi u potrebnom trenutku. Model je usmeren na to da smanji vreme od pojave akutnog stanja do njegovog potpunog medicinskog zbrinjavanja. Vode se zapisnici o ovim procedurama, pomoću kojih se utvrđuju svi projektovani parametri, a na osnovu toga određuje ostvareni nivo upravljanja kvalitetom [12].

Tzv. benchmarking je takođe metoda koja može odrediti dostignuti nivo kvaliteta usluge zdravstvene zaštite, a može se primenjivati na lokalnom, nacionalnom i međunarodnom nivou [7]. Tako, na primer, svaki nivo zdravstvene ustanove, od najvišeg do najnižeg (pojedinac ili odeljenje), može biti reper za tzv. benchmarking. Njihovim poređenjem dobijaju se determinisane vrednosti ostvarenog nivoa kvaliteta usluge. Međutim, ova metoda ima i jedan nedostatak, jer u različitim organizacijama deluju različiti parametri, pa njihovo poređenje na ovaj način nije baš pouzdano.

Metodologije obezbeđenja kvaliteta obuhvataju i korišćenje tehnika samoocenjivanja. One omogućuju zdravstvenoj ustanovi da uoči slabe tačke u modelu pružanja usluga, da ih popravi i time unapredi svoj kvalitet. Ova metoda koristi nekoliko zapisa za praćenje i merenje kvaliteta izvršene usluge (kumulativne karte, histogram itd). Pomoću njih se vrši poređenje planiranih i ostvarenih ciljeva kvaliteta [5].

Varijacija ili analiza varijansi takođe se ubraja u grupu alata za samoocenjivanje ostvarenog nivoa kvaliteta proizvoda ili usluge [4]. Ona omogućuje da se utvrde faktori i njihovi uzroci koji dovode do odstupanja od postavljenih vrednosti.

Danas se u samoocenjivanju kvaliteta usluge sve više koristi profesionalni portfolio. Za ovu tehniku su razvijeni softverski proizvodi, a njena suština je da se definišu okvir potrebne prakse, zahtevi za unapređenje usluga, skup aktivnosti kojima se realizuje usluga, parametri za ocenu efektivnosti usluge i način preispitivanja modela u praksi. Osnovna odlika ove metode je da promoviše i podržava model stalnog unapređenja znanja zaposlenih u oblasti upravljanja kvalitetom.

Jedna od najefektivnijih tehnika upravljanja kvalitetom je pisana saglasnost $[13,14]$. Ona je slična vodičima dobre kliničke prakse, ali je veoma pogodna za primenu u zdravstvenim ustanovama. Zasniva se na tome da se grupa stručnjaka okupi i kroz panel-diskusiju donese zajedničku izjavu o načinu upravljanja kvalitetom određene usluge u zdravstvenoj ustanovi. Osnovno obeležje ove tehnike je da razvija i podržava lokalnu dobru praksu, koju poseduje svaka zdravstvena ustanova.

Tehnika upravljanja kvalitetom koja ima dugu istoriju primene u ovoj oblasti je i kontinuirana edukacija. Ona se zasniva na sistematskom pristupu planiranju, izvođenju, ocenjivanju i preispitivanju izvršene obuke. S druge strane, obuka treba da bude segmentirana i po dubini organizacione strukture zdravstvene ustanove (menadžment, tim za unapređenje kvaliteta, eksperti,...) (Tabela 4) [5].

\section{ZAKLJUČAK}

SZZ je važan aspekt ukupne zdravstvene zaštite u jednoj zemlji. U našoj zemlji ovaj vid zdravstvene zaštite je u poslednjih dvadeset godina doživeo različite promene, posebno organizacione prirode. Danas se ovom vidu zdravstvene zaštite posvećuje posebna pažnja, naročito u oblasti unapređenja kvaliteta usluga. Za to su na raspolaganju različite metode, ali se smatra da je sistem upravljanja kvalitetom važan model koji može da bude dobra osnova za dalja unapređenja modela upravljanja ukupnim kvalitetom i poslovnom izvrsnošću. 